\title{
GREENING OF AGRICULTURAL AND FORESTRY TRACTORS
}

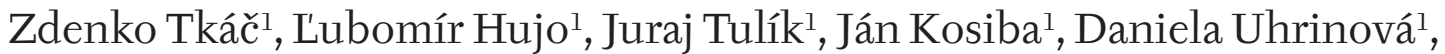 \\ Vladimír Šinský ${ }^{2}$
}

\author{
${ }^{1}$ Department of Transport and Handling, Faculty of Engineering, Slovak University of Agriculture in Nitra, Tr. A. \\ Hlinku 2, 94976 Nitra, Slovak Republic \\ ${ }^{2}$ BIOLIFE, Matuškovská cesta 884/11, 92401 Galanta, Slovak Republic
}

\begin{abstract}
TKÁČ ZDENKO, HUJO LUBOMÍR, TULÍK JURAJ, KOSIBA JÁN, UHRINOVÁ DANIELA, ŠINSKÝ VLADIMÍR. 2014. Greening of Agricultural and Forestry Tractors. Acta Universitatis Agriculturae et Silviculturae Mendelianae Brunensis, 62(5): 1135-1139.

This publication deals with the draft of measurement chain for application of synthetic organic liquid Hydros Uni in agricultural tractor Zetor Proxima 744l. The used organic liquid was evaluated on the basis of its effect on the technical condition of hydrostatic converter UD 20. By the drafted measurement chain, it was performed individual measurements which were realized by specific engine speed and prescribed temperature. Then, the flow values were statistically analyzed. From the obtained results, it could be concluded that the proposed measurement chain meets the requirements for measuring the flow characteristics of liquids. Based on the results show, organic synthetic transmission hydraulic fluid does not negatively affect the technical condition of the tractor hydraulic pump.
\end{abstract}

Keywords: tractor, hydraulic pump, flow characteristics, organic fluid

\section{INTRODUCTION}

Machinery works in agricultural sector is characterized by its demanding operation, contact with primary products and all the elements of the environment. Therefore, it is necessary to examine the idea of the possible harmfulness of agricultural machinery on the environment. In terms of water resources, ground water and soil, it is necessary to address the impact of the used gearbox hydraulic fillings. At present, in most of the agricultural machinery, there are used conventional manufactured mineral liquids. In the case of unforeseen failure, in a very short time period, they are able to largely cause soil and water pollution (Majdan et al., 2011; Hujo et al., 2012). Therefore, the biodegradable fluids on the synthetic and plant base are slowly pushing to forefront. Because of the tightening legislation, it can be expected replacement of conventionally produced liquids with organic ones. The impact of these fluids to different parts of the gear hydraulic circuit of the agricultural machinery has not been fully clear yet. Therefore, it is necessary to perform more laboratory and field testing (Machal et al., 2013; Kosiba et al., 2013). This publication deals with the draft of the measurement chain for such a testing and there is also described the operational examination of organic liquid. This liquid serves as a common gear hydraulic filling in tractors and there is monitored its impact on the technical condition of tractor hydraulic pump.

Due to advantages in renewability and environmental acceptability, bio-sourced and biodegradable hydraulic fluids are increasingly used in fluid power applications (Shick, 2008). In this time, the difference between a conventionally produced fluid and ecological fluid is two or three times of the price. Therefore, it is necessary to look for new solutions how to extend the technical life, which could have an effect on their increased use (Tkáč et al., 2012). The consumption of ecological fluids in the EU is $0.12 \mathrm{Mt}$ per year from total world production of 35 Mt per year (Mosolygó et al., 2008). Almost $50 \%$ of all the sold oils in the world finish at present times as forfeits during the operation in nature (Jakob, 2006). 
Over $60 \%$ of lubricants used in the world are lost in the environment. Vegetable oils are capable to contribute to the goal of energy independence and security since they are a renewable resource (Campanella et al., 2010).

\section{MATERIAL AND METHODS}

\section{Draft of the Measurement for Flow Characteristics Measurements}

Measurement of flow characteristics is an important part in evaluation of the impact of functional fluids for hydraulic pump. Before applying the new fluid in operation is important test it under laboratory conditions. By application of laboratory test device and measuring of flow characteristics under laboratory conditions also published authors Machal et al. (2013), Majdan et al. (2013), Kosiba et al. (2013, 2012), Tulík et al. (2013), Hujo et al. (2012).

To establish a methodology for the flow of hydraulic characteristics of hydraulic pumps measuring, it is needed to set up the components that would be used to achieve the intended results. The most important components include a flow sensor, pressure sensor, temperature sensor, recording unit, load member and joint flange. By the draft of the measurement chain, it is required to follow the certain measurement conditions. The most important condition by measuring of the flow characteristics of hydraulic pumps is the oil temperature. The temperature must be maintained at constant value, because the viscosity of the oil depends on it. At the same time, by measuring of the flow characteristics, the oil temperature must be on operating value. Another extremely important parameter is revolution of hydraulic pump. The hydraulic pump revolution will be monitored based on the combustion engine revolution among which is transference.

To evaluate the fluids in operating conditions, it was drafted the measuring chain with respect to the least possible interference to the operation of the tractor. Methodology proposal for the flow characteristics measurements of hydraulic pump is based on the requirements to simplify testing of hydraulic oils or hydraulic pumps. Previously by operational testing, the hydraulic pump was removed from the tractor to the needs of investigation of the flow characteristics and subsequently it was fitted to the experimental laboratory equipment. This process disturbed the operation of the tractor in an important way and made the test more expensive and prolonged. As a result of this removal and the sequent fitting of hydraulic pump to the tractor or experimental laboratory equipment, it was increased demands on the staff respectively the time spend on these activities. Therefore, it is meaningful to carry out the measurement of hydraulic pumps flow characteristics directly on tractors in compliance the basic conditions, in order to meet the requirements for the accuracy and reliability of measurement results.

The flow, temperature and pressure sensors were placed on the joint flange Hydac. On the both ends of the joint flange Hydac, there were placed gladhands. On the inlet side of the joint flange Hydac (oil inflow from the tractor distributor), there was placed plug-in "male" gladhand and on the output side (oil run-off from the joint flange), there was
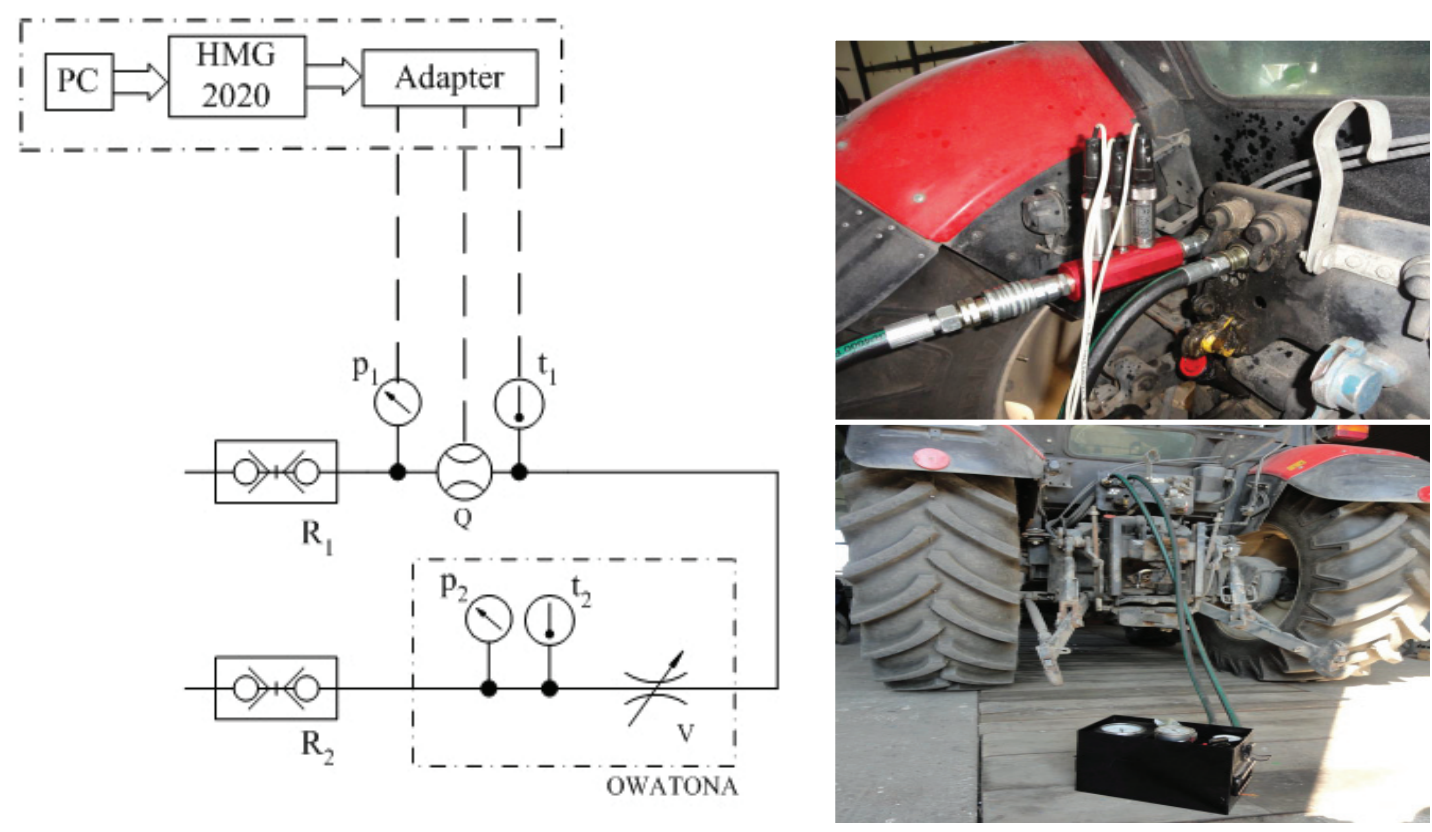

1: Measurement chain schema and measuring elements connection (R1, R2 - gladhands, Q - flow sensor EVS 3100, $\mathrm{p}_{1}, \mathrm{p}_{2}$ - pressure sensors HDA 3774-A-600-000, $\mathrm{t}_{1}, \mathrm{t}_{2}$ - temperature sensors ETS 4144-A-000, V - flow control valve 
I: Combustion engine and hydraulic pump UD 20 revolution

\begin{tabular}{cc}
\hline $\begin{array}{c}\text { Combustion engine revolution } \\
\text { (rpm) }\end{array}$ & $\begin{array}{c}\text { Hydraulic pump revolution } \\
(\mathbf{r p m})\end{array}$ \\
\hline 1000 & 582 \\
1500 & 1023 \\
2200 & 1500 \\
\hline
\end{tabular}

II: Technical parameters of the oil HYDROS UNI

\begin{tabular}{lcc}
\hline \multicolumn{1}{c}{ PROPERTIES } & UNIT & VALUE \\
\hline Kinematic viscosity at $40^{\circ} \mathrm{C}$ & $\mathrm{mm} \cdot \mathrm{s}^{-2}$ & 67.52 \\
Density at $15{ }^{\circ} \mathrm{C}$ & $\mathrm{g} \cdot \mathrm{cm}^{-3}$ & 931 \\
Flash point & ${ }^{\circ} \mathrm{C}$ & 212 \\
Freezing point & ${ }^{\circ} \mathrm{C}$ & -48 \\
Biodegradation to 21 days & $\%$ & 90.4 \\
\hline
\end{tabular}

placed plug "female" gladhand. The measuring device was placed between the exit gladhand from the tractor and loading equipment Owatona. With this loading equipment, it is possible to reach desired operating temperature of the used oil $\left(50{ }^{\circ} \mathrm{C}\right)$ through the throttle valve. The temperature has to be holds on specified value to adjust the measurement errors by reason of viscosity changes (higher temperature $=$ higher viscosity). Also direction of the location of gladhands on the joint flange Hydac is very important due to the fact that the flow sensor EVS 3100 has propeller construction which regulate the direction of the oil flow. Loading equipment Owatona closes hydraulic circuit what ensure the flow of oil through the measuring device. Another extremely important parameter is hydraulic pump revolution. The revolution of the hydraulic pump will be monitored based on revolution of the combustion engine, whereas the internal combustion engine and the hydraulic pump axle ratio $\mathrm{i}=1.467$ reducing. See Tab. I. The used hydraulic pump was UD 20 type. It is one-direction hydraulic gear pump made by the company Jihostroj Aero Technology and Hydraulics. This gear pump is equipped with the hydraulic balancing of axial clearance, which is done by sealing in the end face bearings. It has the application in smaller and medium agriculture and construction machines.

\section{The Object of Measurement}

To choose the agricultural tractor for testing, it was taken into account analysis of the sale of agricultural tractors and the utilization of tractors on farms in Slovakia. By these criteria, it was selected tractor Zetor Proxima 7441. Before application of biodegradable oil, there was removed oil from the gear - hydraulic circuit and transmission - hydraulic circuit was purified. At the same time, the new oil filter was fitted to the tractor. To the gear - hydraulic circuit of the tractor, there was applied selected biodegradable synthetic tractor oil.

\section{Organic Fluid}

For the performance testing, it was selected oil HYDROS UNI, from BIONA JERSÍN, Ltd., Jersín, Czech Republic. HYDROS UNI is versatile biodegradable synthetic oil designed for gearings, hydraulic systems and wet brakes. Technical parameters and biodegradation of the oil are shown in Tab. II.

The time of universal biodegradable oil HYDROS UNI testing in agricultural tractor Zetor Proxima 7441 was set at 2.000 engine hours. This testing interval is determined by the technical specification given by the tractor manufacturer. The flow efficiency of the hydraulic pump was defined from measured values and their statistical processing by standardized normal distribution. Calculation of the flow efficiency is based on the relationship (1) (Majdan et al., 2011).

$\eta_{p r}=\frac{Q_{m}}{V_{G} \times n} \times 100$

if

$Q_{m} \ldots . . . m e a n$ value of the flow $\left[\mathrm{dm}^{3} \cdot \mathrm{min}^{-1}\right]$,

$\mathrm{V}_{\mathrm{g}}$......geometric volume of the hydraulic pump $\left[\mathrm{m}^{3}\right]$, n.......hydraulic pump revolution [rpm].

\section{RESULTS}

\section{The Flow Characteristics of Hydraulic Pumps}

Measurement of the flow characteristics of hydraulic pump for tractor Zetor Proxima 7441 was performed by using the newly proposed measuring chain. Measurement of the flow characteristics was made at the beginning of a performance testing of biodegradable synthetic oil HYDROS UNI. In Fig. 2, there are the flow characteristics and the flow efficiency of tractor hydraulic pump.

The highest flow characteristic was found out at nominal revolution of hydraulic pump. The flow rate of hydraulic pump was deceasing by the all measurement depending on the pressure. 


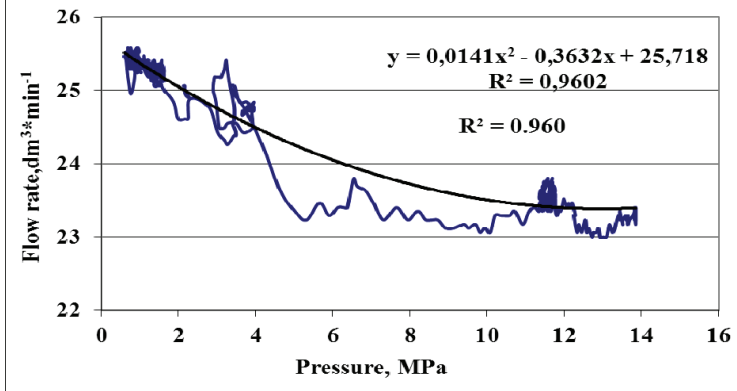

a)

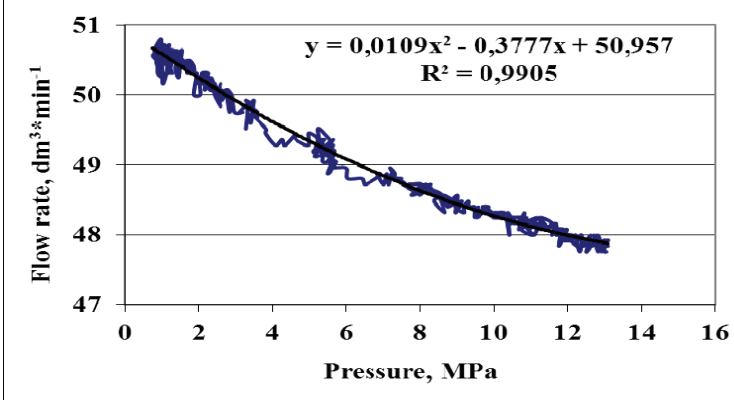

c)

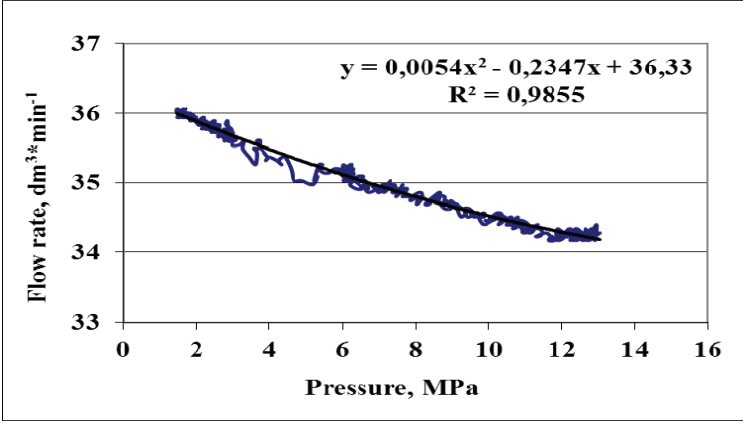

b)

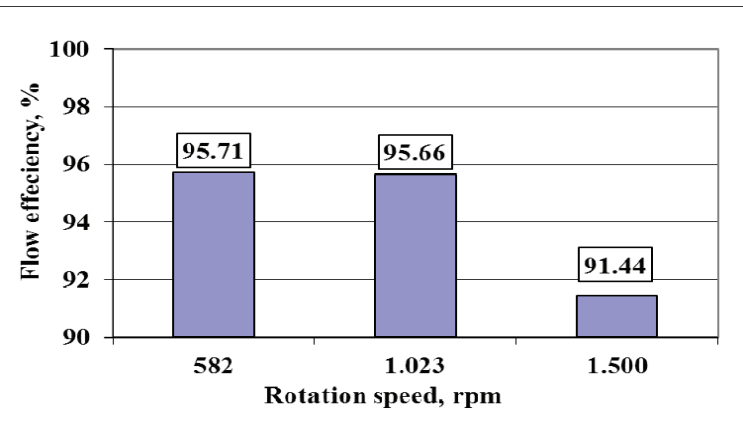

d)

2: The flow evaluation of the fluid testing

(a - flow characteristics at $582 \mathrm{rpm}, b$ - flow characteristics at $1.023 \mathrm{rpm}, c$ - flow characteristics at $1.500 \mathrm{rpm}, d$ - flow efficiency of hydraulic pump)

Application of the standardized normal distribution allows evaluate the measured flow efficiencies in qualitative terms, since not being taken into account all measured data but only $68.27 \%$ of the data from the statistical file. Based on the results of the hydraulic pump flow efficiency, it is possible to state that the liquid had not a negative impact on the technical condition of the converter as it was not exceeded the limit of $20 \%$ decreasing of the flow efficiency set by the manufacturer. The highest flow efficiency was measured at 582 rpm of engine.

\section{DISCUSSION}

There were made application of biodegradable synthetic oil MOL Farm UTTO Synt in agricultural tractor Zetor Forterra 11441. The flow characteristics of hydraulic pump were investigated at experimental laboratory equipment so the hydraulic pump was removed from tractor and then mounted on laboratory equipment. There was not found negative impact of the oil MOL Farm UTTO Synt for hydraulic pump operation located in hydraulic circuit of the tractor by flow characteristics measurements (Kosiba et al., 2013; Tulik et al., 2013; Majdan et al., 2011). Measurements published in this article were executed directly on the tractor in verifying the flow characteristics of hydraulic pump but the conclusion is the same as these authors.

\section{SUMMARY}

In adduced publication, there is proposed and carried methodology for flow characteristics measurement of hydraulic pump directly on the tractor. This proposal was in the next section applied to the tractor Zetor Proxima 7441. The main advantage of this proposal is that it can be virtually applied to all types of agricultural tractors because measurements are carried out through external hydraulic outlets - joint flange. To reduce the negative impact of agricultural tractors activities on the environment, there was applied biodegradable synthetic oil HYDROS UNI in the gear hydraulic circuit of the tractor Zetor Proxima 7441. Operational test of this oil was set at 2.000 engine hours. During the performance test, it was taken oil samples from the tractor at intervals of 250 engine hours. Simultaneously, it was observed the impact of this oil on the flow characteristics of hydraulic pump. The main advantage for praxis is, that was not detected negativ impact on hydraulic pump UD 20 and thus on hydraulic circuit and therefore, the biodegradable fluid is suitable as a substitute 
for conventionally made fluids. The main disadvantage of application of biodegradable oil in the tractor gear - hydraulic circuits is mainly the price of these types of oils. Their price is high more than three times compared to standard mineral oil. Therefore it is not possible wider distribution within the farms in Slovakia at present. To extend the usage of biodegradable oils, it is required legislative intervention by the state respectively taxes or subsidy policy.

Acknowledgement

The research leading to these results has received funding from the European Community under project No. 26220220180: Building Research Centre „AgroBioTech“.

\section{REFERENCES}

CAMPANELLA, A., RUSTOY, E., BALDESSARI, A., BALTANÁS, MIQUEL, A. 2010. Lubricants from chemically modified vegetable oils. Bioresource Technology, 101(1): 245-254.

HUJO, L., KOSIBA, J., JABLONICKÝ, J., TULÍK, J. 2012. Load characteristics of three-point tractor linkage. In: Naučni trudove: zemedelska technika i technologii, agrarni nauki i veterinarna medicina, remont i nadeždnost: zemedelska technika $i$ technologii, agrarnye nauki $i$ veterinarnaja medicina, remont $i$ nadežnost', tom. 51, seria 1.1: 172-176.

JAKOB, K., THEISSEN, H. 2006. Bio-based Oils in Hydraulics - Experience from Five Years of Market Introduction in Germany. Aschen: Institute for Fluid Power Drives and Controls (IFAS), RWTH Aschen University, Germany.

KOSIBA, J., HUJO, L., TULÍK, J., RAŠO, M. 2013. Study of the impact of synthetic fluid on the lifetime of hydraulic pump. Advanced Materials Research, 801(special issue): 7-12.

KOSIBA, J., TKÁČ, Z., HUJO, L., STANČÍK, B. ŠTULAJTER, I. 2013. The operation of agricultural tractor with universal ecological oil. Research in agricultural engineering, 59(spec. iss.): 27-33.

KOSIBA, J., TKÁČ Z, Z., HUJO, L., TULÍK, J., ŠEVČÍK, P., ŠINSKÝ, V., RAŠO, M. 2013. Effect of ecological energy carriers on flow characteristics of tractor hydraulic pump. Journal of Central European Agriculture, 14(4): 1415-1425.

KOSIBA, J., VARGA, F., MOJŽIŠ, M., BUREŠ, L. 2012. Load characteristics of tractor Fendt 926 Vario to simulate on experimental device. Acta Facultatis Technicae, 17(2): 63-72.

MÁCHAL, P., MAJDAN, R., TKÁČ, Z., STANČÍK, B., ABRAHÁM, R., ŠTULAJTER,I,. ŠEVČÍK, P., RAŠO, M. 2013. Design and verification of additional filtration for the application of ecological transmission and hydraulic fluids in tractors. Acta Universitatis Agriculturae et Silviculturae Mendelianae Brunensis, 61(5): 1305-1311.
MÁCHAL, P., TKÁČ, Z., KOSIBA, J., JABLONICKÝ, J., HUJO, L., KUČERA, M., TULÍK, J. 2013. Design of a laboratory hydraulic device for testing of hydraulic pumps. Acta Universitatis Agriculturae et Silviculturae Mendelianae Brunensis, 61(5): 13131319.

MAJDAN, R., KOSIBA, J., TULÍK, J., KROČKOVÁ, D., ŠINSKÝ, V. 2011. The comparison of biodegradable hydraulic fluid with mineral oil on the basis of selected parametres. Research in agricultural engineering, 57(special issue): S43-S49. MAJDAN, R., TKÁČ, Z., ABRAHÁM, R., STANČÍI, B., KUREKOVÁ, M., PAULENKA, R. 2013. Effect of ecological oils on the quality of materials of hydraulic pump components. Advanced Materials Research, 801(special iss.): 1-6.

MAJDAN, R., TKÁČ, Z., KOSIBA, J., ABRAHÁM, R., JABLONICKÝ, J., HUJO, L'., MOJŽIŠ, M., ŠEVČÍK, P., RÁŠO, V. 2013. Evaluation of tractor biodegradable hydraulic fluids on the basis of hydraulic pump wear. Research in agricultural engineering, 59(3): 75-82.

MOSOLYGÓ, E., JÁNOŠÍK, Š. 2008. Lubricants based on renewable resources. In: Interfaces'08. Sopron: Slovnaft a. s., Member of the MOL Group, 111-120.

SHICK, D. 2008. Compatibility testing of biodegradable hydraulic fluids. [online]. Available at: http://www. msoe.edu/academics/research_centers/reu/ pdf/2008/Compatibility\%20Testing\%20of\%20 Biodegradable\%20Hydraulic\%20Fluids.pdf. [Accessed: 03-02-2012].

TKÁČ, Z., MAJDAN, R., TULÍK, J., KOSIBA, J. 2012. Study of ecological fluid properties under operational conditions of tractors. In: TEAM. Osijek-Baranja: University of Josip Juraj Strossmayer, 4(1): 295-298.

TULÍK, J., HUJO, L., STANČǏIK, B., ŠEVČǏK, P. 2013. Research of new ecological synthetic oil-based fluid. Journal of Central European Agriculture, 14(4): 1384-1393.

Zdenko Tkáč: zdenko.tkac@uniag.sk

Lubomír Hujo: lubomir.hujo@uniag.sk

Juraj Tulik: juraj.tulik@gmail.com

Ján Kosiba:jan.kosiba@gmail.com

Daniela Uhrinová: daniela.uhrinova@uniag.sk

Vladimír Šinský: vladimir.sinsky@biolife.sk

Contact information 